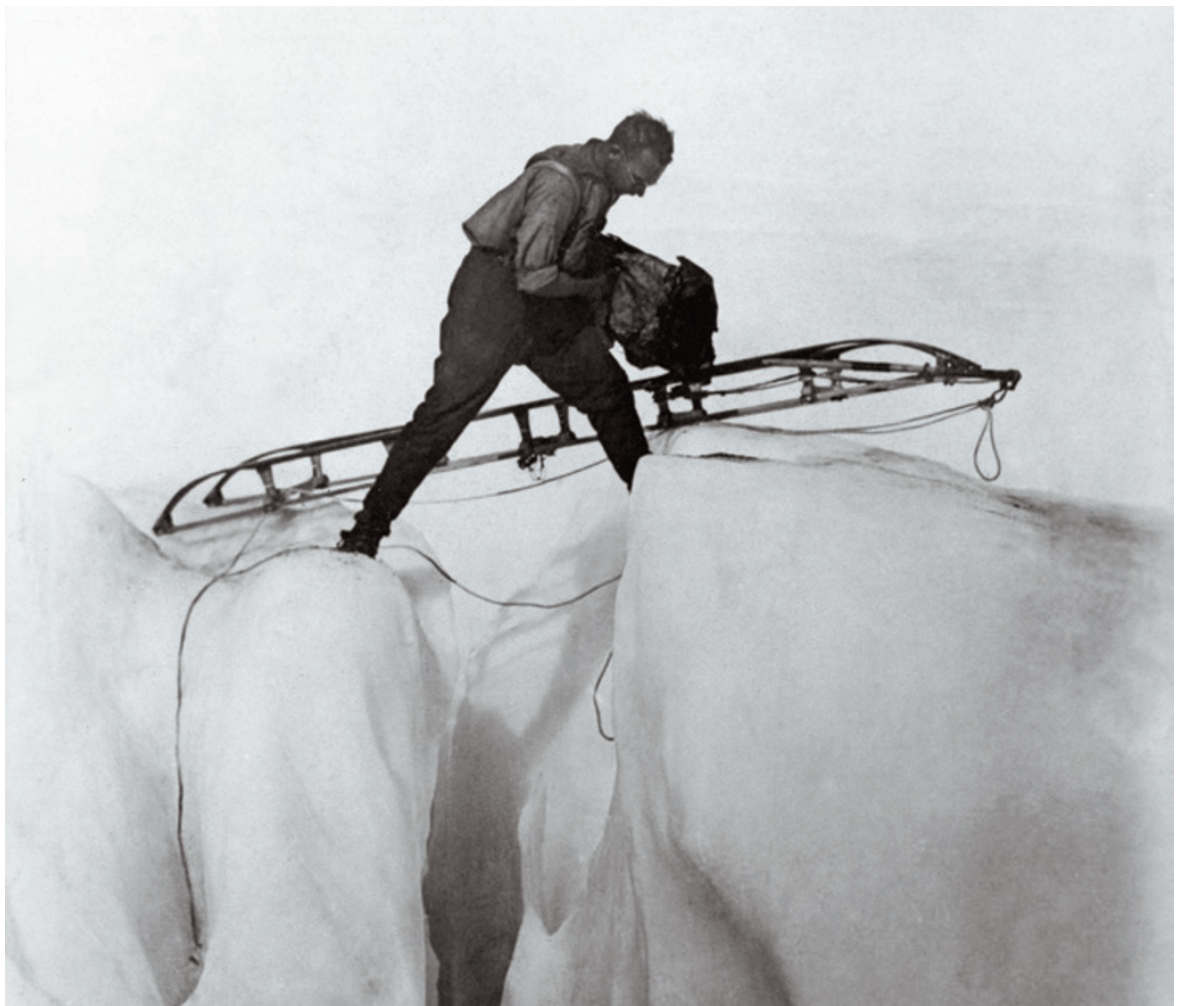

Alfred Wegener crossing a glacier on his final, fatal expedition to Greenland, in 1930.

\title{
GEOLOGY
}

\section{The continental conundrum}

\section{Ted Nield hails a biography of Alfred Wegener, who proposed the theory preceding plate tectonics.}

\section{$\mathrm{T}$} There is a moment in Star Wars: The Empire Strikes Back (1980) that neatly encapsulates two contrasting scientific types. An officer reports a lead from a drone sent to find a rebel hideout. Admiral Ozzel dismisses his claim with statistical objections; Darth Vader takes one look and says, "That's it. The rebels are there." Such intuitive certainty characterized the discoverer of continental drift, Alfred Wegener, subject of science historian Mott Greene's muchanticipated biography. Wegener saw what others missed and knew that he was right and mostly was. The force was with him.

Every geoscientist has heard of Wegener (1880-1930). Yet we have waited 85 years for a biography to explain who he was and what he achieved beyond the one thing that made him immortal. In this vacuum, myths have proliferated. Almost everything most geologists think they know about Wegener (that as a 'meteorologist' he was an 'unknown outsider', for instance) is wrong. Greene beautifully puts the record straight with a portrait of Wegener as a respected 'cosmic physicist': trained in astronomy, Wegener applied physics to the observable Universe, from stars and planets to Earth's atmosphere, crust and interior.

Wegener was born in Berlin, to Anna Schwarz and clergyman, classicist and pedagogue Richard Wegener. His childhood was one of hard work and outdoorsy self-discipline. Sharing his lifelong need for physical exertion with his older brother and fellow explorer Kurt, Wegener developed a love of ballooning that led to their 1906 world record of 52.5 hours of continuous flight. His passion for the outdoors led him towards understanding the natural world through physics.
The tenor of his life was set. Wegener made three gruelling expeditions to Greenland - which Greene graphically recounts. His dogged pursuit of scientific data, notably on the structure of the upper atmosphere and the zones of shear between its component layers, verged on the superhuman.

Wegener's way of working became evident as early as 1909 .

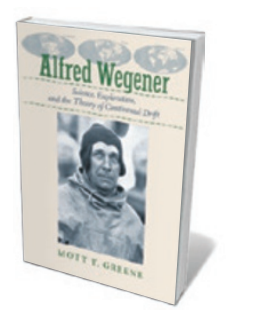

Alfred Wegener: Science,

Exploration, and the Theory of Continental Drift MOTT T. GREENE

Johns Hopkins

University Press: 2015.
In a paper about the layered structure of the atmosphere, he took others' published data and made connections they had missed to propose a simpler, more elegant conclusion. Similarly, in 1911, Wegener made his wild surmise about the westward drift of the Americas, after first looking into Richard Andree's great work, his world map Allgemeiner Handatlas (1881). Wegener was not the first to notice the fit between the Atlantic Ocean's opposing shores - more specifically, between the continental-shelf margins of South America and Africa. But in 1912, he was the first to hypothesize that the Atlantic is young, formed as the Americas drifted away from Europe and Africa - an idea developed more fully in 1915 (see also M. Romano and R. L. Cifelli Nature 526, 43; 2015). He also posited that all continents had once been grouped as a supercontinent, Pangaea.

The contemporary orthodoxy proposed by Austrian geologist Eduard Suess held that the Earth was shrinking, causing parts of continents to founder and marooning populations of similar animals in widely separated lands. Wegener recognized this as physically impossible. The principle of isostasy - developed by nineteenth-century geophysical theorists John Henry Pratt, George Biddell Airy and Osmond Fisher - had shown that rafts of continental rock 'float' in the denser material of the Earth's mantle; continents cannot 'sink'. To Wegener, it was more elegant to assume that the continents moved laterally. The fit of the Atlantic coastlines was, for him, too convincing to be a coincidence. How they moved was something for future research.

This was the thinking of a physicist. Yet initially, most physicists (and geologists, including influential figures such as US Geological Survey engineer Bailey Willis) rejected the idea. Geologists in Europe and South Africa converted first, perhaps because their wider knowledge of global geology led them to stronger supporting evidence. Most US scientists held out until the 1950s, usually citing a lack of mechanism. But their scepticism had more to do with the culture of US science, which, in contrast to Wegener's approach, 
relied on considering multiple hypotheses. The vehemence of the debate hints, too, that their rejection was more of Old World hierarchies than of Wegener's theory.

Indeed, the barriers were largely sociological, as Greene shows. Wegener was born at the wrong time. The First World War interrupted his career, and began the long isolation of German scientists just when his great idea most needed discussion. He also fell between disciplinary stools. He published important contributions on astronomy, meteoritics, atmospheric science, climatology, palaeoclimatology, geology, geophysics, geodesy and glaciology. When he died aged just 50 in 1930, from a heart attack on the Greenland ice sheet, he left no disciples. 'Cosmic physics' broke up like a supercontinent.

As a result, Wegener makes a challenging subject, which Greene tackles through extensive archival research, travel and circumstantial evidence. Wegener left no extensive notebooks; much of his unpublished writing was destroyed by war or neglect, and he was not given to personal revelation. Like many polar explorers, he was wrapped up in his work. It seems amazing that Wegener married, until we realize that his wife, Else, was the daughter of his collaborator, émigré Russian climatologist Wladimir Köppen.

Others have covered aspects of the enigmatic geoscientist's legacy. Henry Frankel published the comprehensive four-volume The Continental Drift Controversy in 2012 (Cambridge Univ. Press); Naomi Oreskes expertly explored US opposition to the theory in The Rejection of Continental Drift (Oxford Univ. Press, 1999). Greene's full picture of the man is set masterfully within the wider development of the subjects on which he exerted influence (or failed to). If this wonderful book has a weakness, it is a dearth of illustrations; but those on show include many previously unpublished expedition pictures.

Following the advice of Michael Faraday's biographer L. Pearce Williams, Greene has "read everything his subject wrote, everything he read, and as much as possible of what the people he read, read". He has also travelled everywhere Wegener went, including Greenland. The labour has taken more than 20 years. The result is a magnificent, definitive and indefatigable tribute to an indefatigable man.

Ted Nield is the author of Supercontinent. His latest book is Underlands. e-mail:ted.nield@ geolsoc.org.uk

SCIENCE FICTION

\section{Crusoe on Mars}

\section{Elizabeth Gibney relishes Ridley Scott's disco-laced chronicle of survival on the Red Planet.}

W atching The Martian might disturb your dreams, but it will not give you nightmares. Veteran director Ridley Scott's Mars is dirty, rugged and perilous, yet the lingering impression is of a planet more rose-tinted than red.

The Martian tells the story of NASA astronaut and botanist Mark Watney (Matt Damon), stranded alone on Mars after his crew is forced into an emergency evacuation. Believing him dead, the team heads back to Earth, leaving Watney to work out how to survive until NASA can launch a rescue mission. Despite being faced with unimaginable loneliness, and probable death, Damon's Watney seems bizarrely chipper. This danger-riddled film is almost absurdly fun.

Cheeriness in the face of peril is a new turn for Scott. Bar his much-derided A Good Year (2006), the director of Gladiator (2000) and Alien (1979) does not really do comedy. The Martian inherits much of its wit from the source novel, originally self-published by writer Andy Weir in 2011. Its irreverence also owes much to scriptwriter Drew Goddard, whose work includes television's Buffy The Vampire Slayer. Thanks in large part to Damon's likeably wry portrayal of Watney, the tone works. You are happy to share his company for the duration, particularly given the joyful, mostly disco soundtrack.

In his crew's habitat, or 'Hab', Watney has an array of solar panels and apparently unending rolls of duct tape. But food is limited, and to grow his own he must source water (he manages by burning hydrazine from rocket fuel). After last year's Christopher Nolan blockbuster Interstellar (Z. Merali Nature 515, 196-197; 2014), Damon might seem to be repeating the role of abandoned astronaut, but there are few parallels. The Martian is strong on the workings of science logic, problem-solving and perseverance - in contrast to Nolan's rather pompous affair. Ridley gives us failures as well as the triumphs - and

Matt Damon in The Martian. includes geeky shout- The Martian outs to the second law RIDLEY SCOTT of thermodynam- 20th Century Fox: ics, the hexadecimal 2015.

system and radioisotope thermoelectric generators. There is also Watney's heavily trailed quote that the only way to survive is to "science the shit out of this".

Some press reports have focused on Weir and Scott's efforts to get the science right. And it is true that if humans were to go to Mars - a NASA goal for the 2030s - the set-up would probably resemble that in the film. Missions are run in stages, with equipment sent ahead. The crew dawdles on space trips many months long, and once on Mars, scrabbles to collect the perfect soil sample. Yet the science is hardly faultless. Mars's low gravity would be more visible in the astronauts' gait. The thin atmosphere would make radiation one of Watney's main concerns. But when human spirit and ingenuity are the heart of the film, dwelling on these elements seems unfair.

Given The Martian's fantastic cast, it is a shame that only Damon is allowed to shine. Kristen Wiig, as NASA's director of media relations, too often stands wide-eyed in the background when the public-relations roller coaster of the plot should have brought her character to life. Jeff Daniels as the NASA administrator could have been a cynical counterbalance to the pure-as-snow researchers, but he, too, is one of the good guys.

The film has been praised for its diversity, and there appear to be more women and ethnic-minority staff at The Martian's fictional NASA than in the real agency. Chiwetel Ejiofor enjoys himself playing Vincent Kapoor, head of Mars missions. Jessica Chastain is perfect as serious but warm-hearted mission-commander Melissa Lewis. There are two female crew members, both worthy role models; but whereas several of the male astronauts have children, neither of the women does - perhaps a disappointing hint that space and motherhood do not go together.

The Martian is more feel-good than 2013's Gravity, and lighter than Interstellar. Watney's psyche is left largely unexplored. Where the other two blockbusters invite the audience to stand in awe of nature as a mighty beast, The Martian asks you to saddle it. Enjoy the ride.

Elizabeth Gibney reports on physical sciences for Nature from London. 